\title{
日本における1時間降水量の極值と 地上観測気温の関係
}

\section{RELATIONS OF HOURLY PRECIPITATION EXTREMES AND TEMPERATURE OVER JAPAN BASED ON GROUND OBSERVATIONAL RECORDS}

\author{
内海信幸 1 ・瀬戸心太 ${ }^{2} \cdot y_{11}$ 信次郎 $3 \cdot$ 沖大幹 4 \\ Nobuyuki UTSUMI, Shinta SETO, Shinjiro KANAE, and Taikan OKI \\ 1正会員 修士（工学） 東京大学 生産技術研究所（广153-8505 東京都目黒区駒場4-6-1） \\ 2正会員 博士（工学） 東京大学 生産技術研究所（广153-8505 東京都目黒区駒場4-6-1） \\ 3正会員 博士（工学） 東京工業大学 情報理工学研究科（广152-8552 目黒区大岡山2-12-1） \\ 4正会員 博士（工学） 東京大学 生産技術研究所（广153-8505 東京都目黒区駒場4-6-1）
}

\begin{abstract}
Changes of the intensity and the frequency of extreme precipitation under climate change are great concerns to scientists and policy makers.

We analyzed the $99^{\text {th }}$ percentiles of 1-hour precipitation for each temperature bin based on the ground observational data. The result showed that, first: the $99^{\text {th }}$ percentiles of 1-hour precipitation tend to increase exponentially with the rising temperature, second: the rate of the precipitation increase was almost same as the Clausius-Clapeyron like relation for most part of Japan, except that the rate was larger for lower latitude region, third : the $99^{\text {th }}$ precipitation intensities tend to have a peak at higher temperature.
\end{abstract}

Key Words : hourly precipitation, extreme, temperature, Clausius-Clapeyron, Japan

\section{1. はじめに}

気候変動によって降水現象の強度や発生頻度がどの ように変化するかはメカニズム自体が科学的に興味深 いテーマであるとともに，防災計画や政策立案の面か らも重要な事項である．世界の陸域の多くでは豪雨の 発生頻度は増加していると報告されている11. また日本 についても降水強度や頻度の変化を時系列で解析した 研究が行われている (例えばKanae et al. ${ }^{2}$, Fujibe et al. ${ }^{3}$ ) ）

気候変動が降水現象を変化させると推論する際の主 なメカニズムのひとつは, 気温上昇による大気中の可 降水量の増加である. 気温が上昇すると大気の飽和水 蒸気圧は指数関数的に増加する. これは熱力学の式で あるClausius-Clapeyronの式によって決まり，さらに飽和 比湿の変化率を求めると, その変化率は6.5 7.0\% $9 \mathrm{C}$ 程 度である.これについて例えばThrenberth et al. ${ }^{4}$ は豪雨 の強度が大気下層における水蒸気の収束に大きく依存 していることから, 気温上昇に伴う豪雨の強度の変化 は大気中の水蒸気量変化と同等か, 場合によっては水 蒸気の凝結による潜熱放出によって水蒸気量変化率以 上の降水強度増加がみられる可能性を述べている．ま た, 気候モデルによる気候変動シミュレーションの出 力值を用いて豪雨の変化や頻度の変化のメカニズムを
探る研究も行われている (Emori and Brownm5), O'Gorman and Schneider ${ }^{6}$ など）。しかしながら用いられ る気候モデルによって豪雨の変化の傾向が異なるなど (Sugiyama et al. ${ }^{7}$ ) ), 依然として気候モデルを使った分 析には不確実性が大きい.

このため観測データを用いた分析も行われているが (Allan and Soden ${ }^{8}$, Berg et al. ${ }^{9}$ など)，多くは1日降水量 を対象としたものである.1時間降水量観測值を分析し たものには，ヨーロッパを対象に1時間降水量と地上気 温の関係を分析したLenderink and Meijgaard ${ }^{10,11)}$ がある. 彼らは，1時間降水量の極值がある程度の気温までは飽 和水蒸気量の変化に非常に近い変化率を示し, 気温が より高くなると飽和水蒸気量の変化率を降水強度の変 化率が上回る傾向を見出した．しかしこうした分析は 対象地域がヨーロッパに限られている. 高温で降水強 度変化率が大きくなるという彼らの結果は $22^{\circ} \mathrm{C}$ 程度ま での比較的低い気温範囲を分析したものであり，こう した結果がより高い気温範囲を含む日本域についても 見られるようなものかどうか，そもそも気温上昇に よって1時間降水量の極值が増加する傾向は一般的なも のであるのかが不明である.

そこで本研究では，a）そもそも極端な1時間降水量 と気温の間の正の相関関係はヨーロッパ以外でも確認 
できるか，b）正の関係が確認できる場合，その変化率 はヨーロッパ同様に水蒸気量変化に近いものとなるか, c ）既往の研究では $22^{\circ} \mathrm{C}$ 程度までの気温のみを解析し, 降水強度が気温と共に大きくなる傾向が示されたが, より高い気温範囲を含む地域でもこの傾向は持続する のか, といった疑問を背景とし, 既往の研究ではカ バーされなかった比較的気温の高い地域までを含む日 本域を対象に1時間降水量の極值と地上気温の関係を分 析した.

\section{2. 地上気温と99パーセンタイル1時間降水量}

\section{（1）方法}

降水量および気温のデータとしてAMeDASによる1時 間ごとの地上観測值を用いた．対象とする期間は1976 年〜2006年の31年間とし，対象期間を通して久測が少 ない約670箇所のデータを用いた。

主にLenderink and Meijgaard ${ }^{10), 11)}$ の手法にしたがって地 上気温と降水強度を対応付けた解析を行った。

まず，対象地点それぞれについて対象全期間から降 水が観測された時刻のデータを抽出する. 本稿では各 タイムステップ (ここでは1時間）で降水が観測された 場合，それを「降水イベント」と呼ぶこととする。

次に各降水イベントについて, 降水イベントの発生 時刻・発生前12時間・発生後11時間の計24時間の気温 を平均し， $2^{\circ} \mathrm{C}$ 幅の気温ビンに分類する. こうして作成 された1時間降水量と24時間平均気温ビンのセットから， 気温ビンごとに降水量の99パーセンタイル值を計算し た. 1時間の降水イベントに前後の時間を含む24時間の 平均気温を対応させるのは, 降水イベント自体が気温 に与える影響をできるだけ除くためである. また，時 間に幅を持たせて平均を行うことは観測地点へ流入す る大気の平均的な気温を捉えていることになり，空間 的な平均を行うことと同等であると考えている．なお 本稿では図を示さないが, 降水イベント発生時刻の気 温のみを使って同様の解析を行った場合も, 結果に大 きな違いは見られなかった。

99パーセンタイル降水量の計算にはノンパラメト リックな手法とパラメトリックな手法が考えられる. 確率分布を仮定するパラメトリック手法による推定值 は, 仮定する分布の選択やパラメータ決定方法に影響 される. 例えば降水量極值の推定にしばしば用いられ る一般化パレート分布は, ある閾值以上の值をとる データを用いてパラメータの推定を行うが, 本研究で 行うような気温ビンごとの99パーセンタイル值の推定 に適用したところ，推定值が間值の取り方に非常に敏 感であり, 不安定であった。このため本研究ではノン パラメトリックな手法を用いて推定を行うこととした. 推計結果の集計は図-1に示したように気候区を元に分 類した地域ごとに行った.

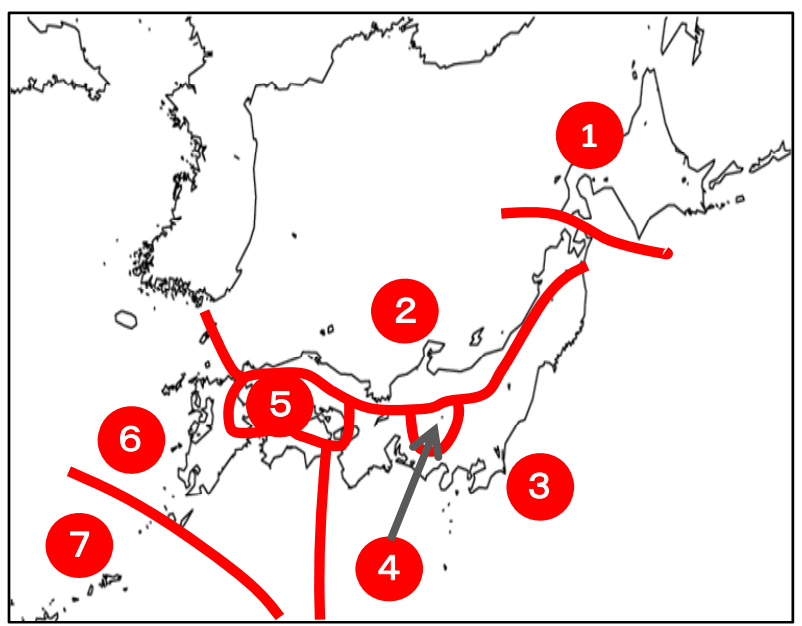

図- 1 対象領域区分と領域番号

（2）結果

1時間降水量の99パーセンタイル值と気温の関係を図2に示す. 縦軸は対数軸をとっている. 99パーセンタイ 儿降水量を各観測地点について個別に求め, その結果 を気候区ごとに平均してあり，季節による傾向の違い を確認するため冬季（1-3月）と夏季（7-9月）について 解析を行っている. 参考までにClausius-Clapeyronの式か ら推定される飽和水蒸気圧の変化も図中に点線で示し ている. Clausius-Clapeyronの式から求められるのは気温 上昇に伴う飽和水蒸気圧の「変化率」のみであり, 点 線は上下の位置は意味を持たず，その傾きのみが意味 を持つ点に注意されたい.

まず，最も緯度の低い領域7を除き，どの地域におい ても気温の上昇に伴って99パーセンタイル降水強度は 増加する傾向が冬季・夏季ともに確認できる．増加の 傾向は指数関数的である（図の縦軸が対数軸であるこ とに注意）。ただし夏季には $25^{\circ} \mathrm{C}$ 前後で降水強度の ピークとその後の減少が確認できる. 最も緯度の低い 領域けは冬季においても降水強度がピークを迎え，その 後減少する傾向が見られる。ただし，その気温は $20^{\circ} \mathrm{C}$ 程度である.また，領域7の夏季の気温帯は $25^{\circ} \mathrm{C}$ 以上で あり, 降水強度のピークは見られず, 常に降水強度と 気温の関係は負である。降水強度が減少に転じる気温 は季節によって異なっている．また，降水強度がピー ク值を迎えるまで降水強度増加率を見ると, 領域6や領 域7などの低緯度で大きな増加率を示寸傾向が見られる.

\section{3．季節・地域別の降水強度変化率とピーク気温}

（1）方法

ある程度の気温まで降水強度と気温は正の関係を示 し，より高い気温においてはその関係が負に転じるこ とが図-2で示された。 ここでは本研究の背景となった疑 問の一つである「降水強度と気温の間に正の関係が確 
認でできる場合, その変化率はヨーロッパ同様に水蒸 気量変化 $\left(\right.$ 約 $\left.7 \%{ }^{\circ} \mathrm{C}^{-1}\right)$ に近いものとなるか」を定量的に 確認するため, 次のように降水強度の平均変化率を求 めた。 変化率の計算は降水強度と気温の関係が負に転 じる気温（以下，ピーク気温と呼ぶ）よりも低い気温 のみを対象とし, 観測所毎に変化率を算出し, それを 領域単位で平均した。 また，パーセンタイルの取り方 によって降水強度の変化率がどのように異なるかを調 ベるため，99パーセンタイル降水量に加え，90，75， 50パーセンタイル降水量についても変化率の計算を 行った. 99パーセンタイル降水量の概念図を図-3に示し て説明する．図中の気温ビンTにおける変化率を計算す
る場合を考える. 図中黒線が実際の観測データから計 算された99パーセンタイル降水量を示し, 気温ビン Tprev, Tnextはそれぞれ気温ビンTを挟む前後の気温ビ ンである。まず図中の線分AC上で気温ビンTに対応す る点を点 $\mathrm{B}^{\prime}$ と, 線分 $\mathrm{BB}$ ' 中点 $\mathrm{M}$ に対応する降水強度 PMを求める. 次に気温ビンTprevとTnextのあいだの降 水強度の平均変化量 $\left(\mathrm{mm} / \mathrm{h} /{ }^{\circ} \mathrm{C}\right)$ を求め, これを降水強 度PM $(\mathrm{mm} / \mathrm{h})$ で除し，最後に単位を（\%/C $\left.{ }^{\mathrm{C}}\right)$ で表現 するため100を乗じる。 これを気温ビンTにおける降水 強度の変化率とした。 さらに，こうして求めた各気温 ビンの変化率を $0{ }^{\circ} \mathrm{C}$ からピーク気温まで平均し, 降水強 度の平均変化率とした。


region 5
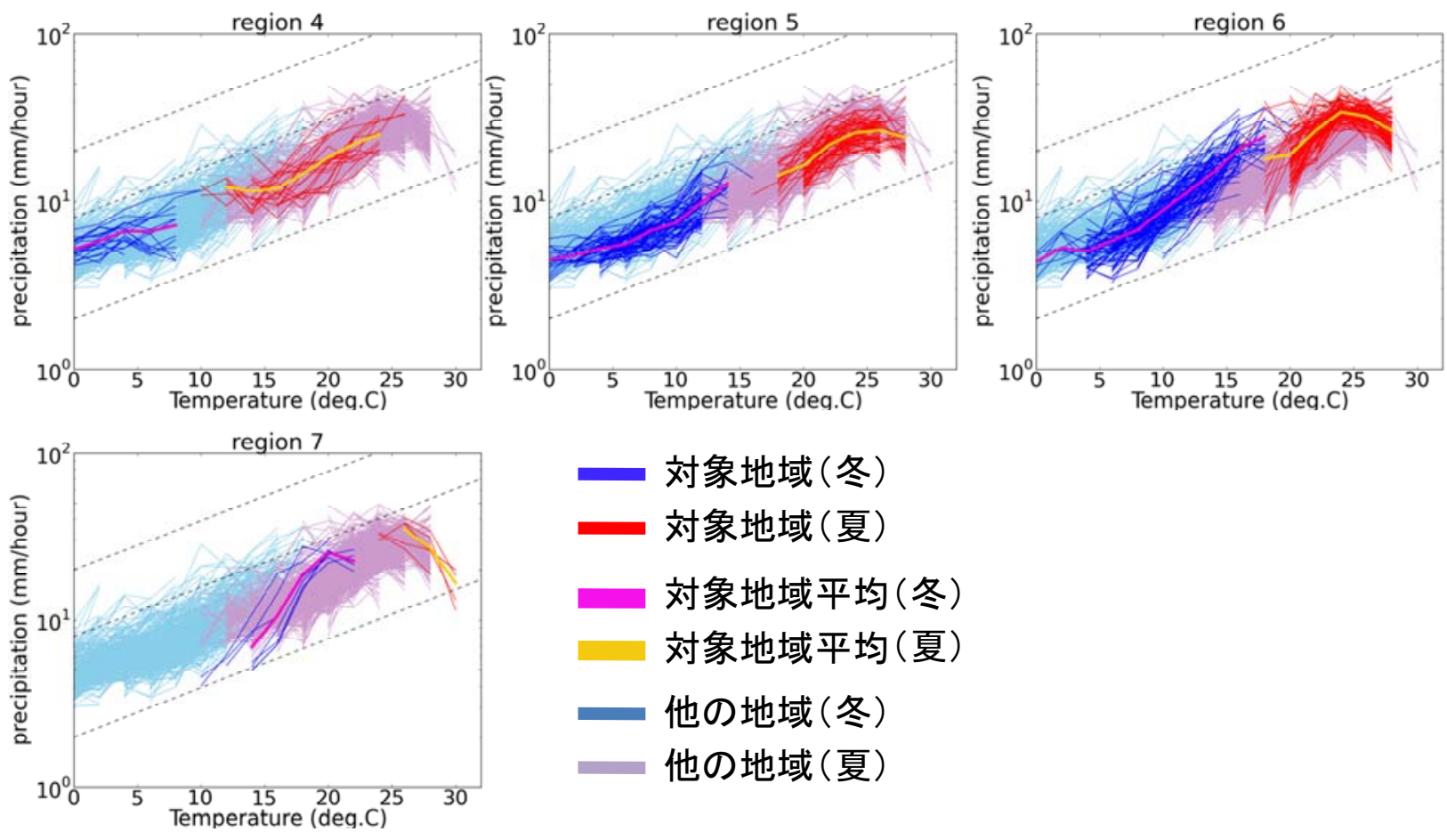

\section{- 対象地域(冬)}

対象地域(夏)

対象地域平均 (冬)

対象地域平均 (夏)

他の地域 (冬)

他の地域(夏)

図- 2 1時間降水量の99パーセンタイル值と気温の関係（気候帯別・季節別）

各気候区における1時間降水量の99パーセンタイル値と地上気温の関係を冬季1-3月（青色），夏季7一9月（赤色）について示し ている. 赤紫太線と黄色太線はそれぞれ冬季・夏季における対象地域の平均値. 地域間の比較を容易にするため, それぞれの図の 背景に対象領域以外の地域の結果を水色細線（冬季）・薄紫細線（夏季）で示している.縦軸は対数軸であることに注意. 参考のた め, Clausius-Clapeyronの関係から予想される水蒸気量変化率 (およそ7\% $\left.{ }^{\circ} \mathrm{C}^{-1}\right)$ を黒点線で示している. 黒点線は傾きのみが意味を 持つことに注意. 


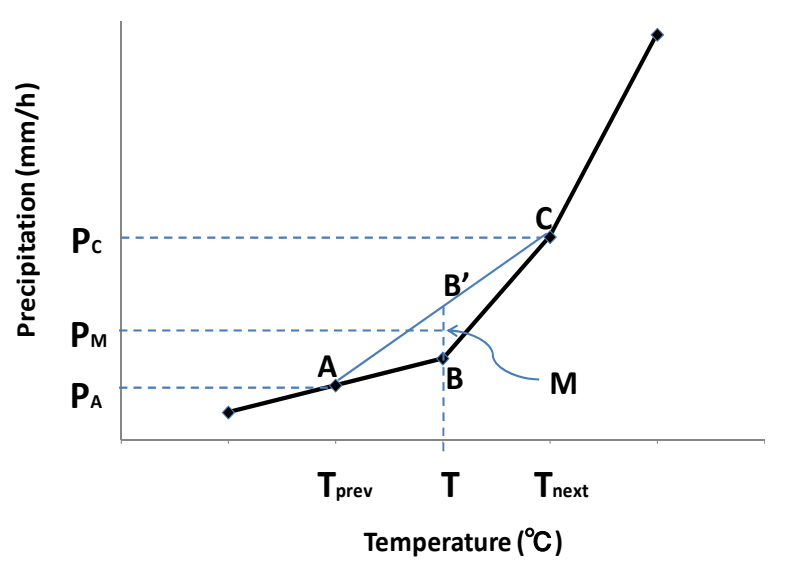

図- 3 降水量強度変化率の計算方法

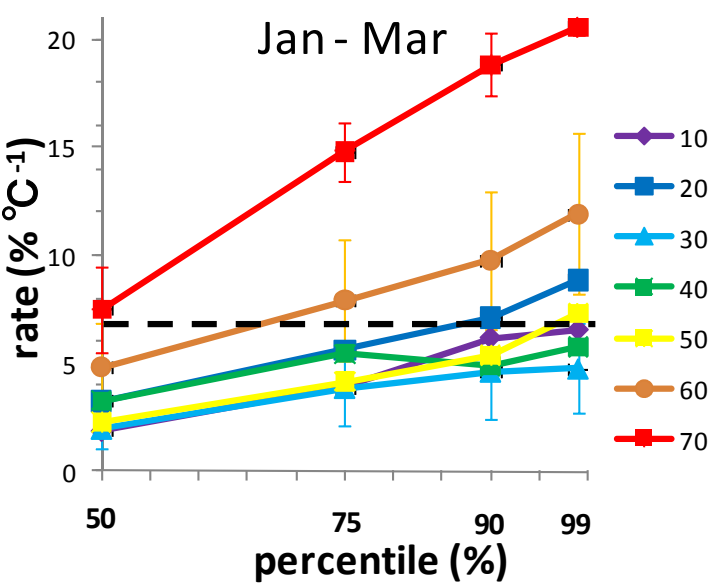

(2) 結果

a) 地域別の降水強度変化率

図- 4に気温変化に伴う1時間降水強度の平均変化率を 地域別・パーセンタイル別に示す。図には比較のため, Clausius-Clapeyron $の$ 関係から予想される飽和水蒸気量変 化率 $\left(7 \%{ }^{\circ} \mathrm{C}^{-1}\right)$ を黒点線で示してある.

まず冬季からみる．領域4（本州内陸部）において90 パーセンタイル降水量の変化率が75パーセンタイル降 水量の変化率よりわずかに小さいものの，全体として は50パーセンタイル降水量から99パーセンタイル降水 量まで，稀な降水になるほど気温変化に伴う降水強度 の変化率（増加率）は大きくなる傾向が見られる．最



図- 4 気温変化に伴う1時間降水強度の平均変化率

各色番号は地域番号を示している. 夏季の領域70 (沖縄周辺) では降水強度と気温の間に正の相関が見られなかったため表示して いない. また, 黒点線は $7 \%{ }^{\circ} \mathrm{C}^{-1}$ を示す. 空間的なばらつきの目安として，10幅をエラーバーで示している. ただしエラーバーは図 の視認性を考慮して領域30, 領域60，領域70のみに表示した.

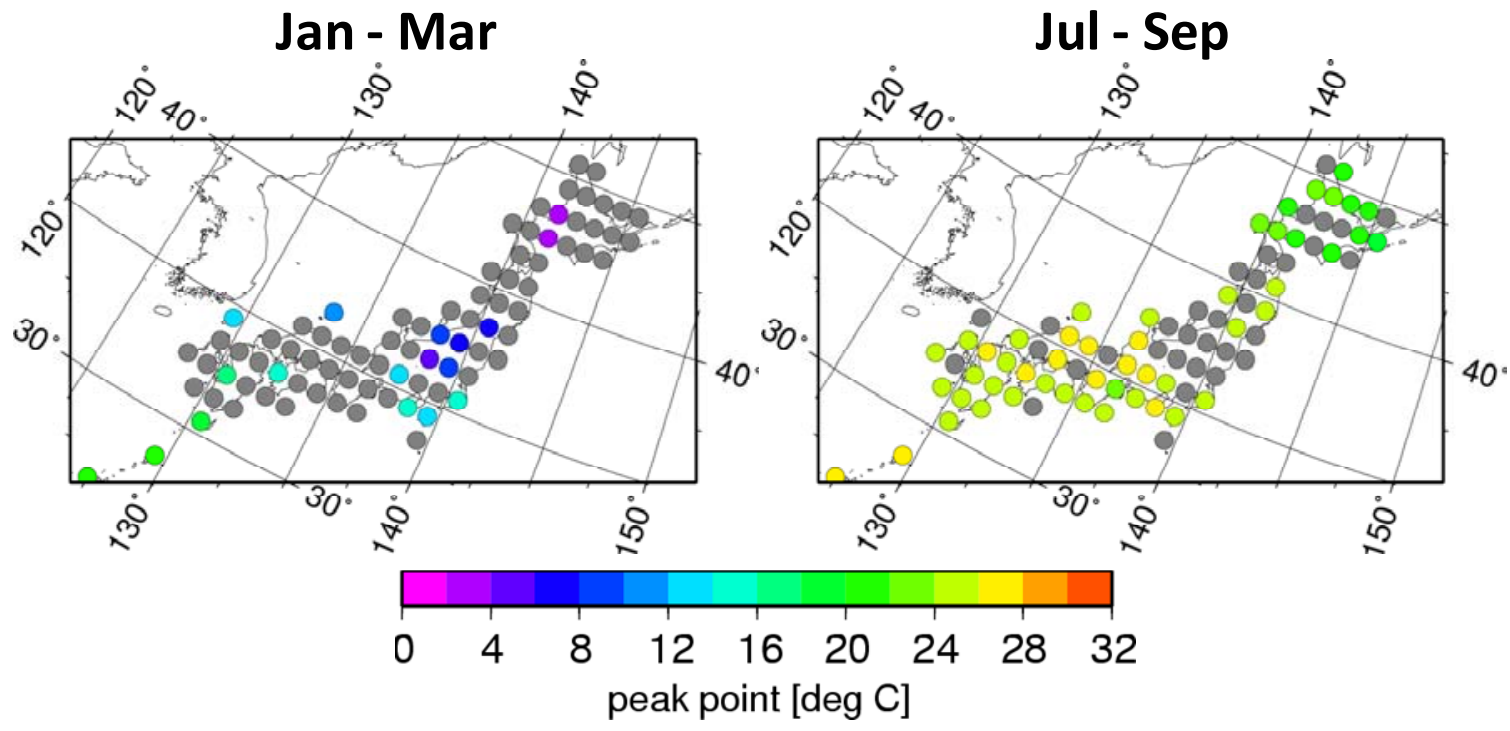

図- 5 99パーセンタイル降水量のピークに対応する気温ビン

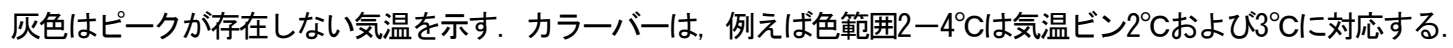


も強い降水である99パーセンタイル降水強度の変化 率は，領域7（沖縄周辺）の值の大きさが顕著であ り，続いて領域6（九州・四国南部）も $12 \%{ }^{\circ} \mathrm{C}^{-1}$ と大 きな值を示している. 領域1～5では飽和水蒸気量の 変化率に近い約 $7 \%{ }^{\circ} \mathrm{C}^{-1}$ を心として 4 \% $9{ }^{\circ} \mathrm{C}^{-1}$ 程度 に分布している.

次に夏季の結果をみる. 夏季の領域7 (沖縄周 辺）では降水強度と気温の間に正の関係が確認され なかったため, 結果は領域1〜6についてのみ示して いる. 夏季においても冬季と同様に, 稀な降水にな るほど気温変化に伴う降水強度の変化率（増加率） は大きくなる傾向が見られる．領域間の差は小さく， さらに99パーセンタイル值の変化率については水蒸 気量変化率の $7 \%{ }^{\circ} \mathrm{C}^{-1}$ よりわずかに大きく, $8.5 \%{ }^{\circ} \mathrm{C}^{-1}$ 程度を中心に分布している.

b) 99パーセンタイル降水量のピークと減少

図-4は降水強度が減少に転じる点, つまり99パー センタイルのピークに対応する気温ビンの地域分布 である．減少が見られなかった地域は灰色で示して いる. 99パーセンタイル降水量のピークが存在する 地域は夏には主に西日本を中心に広がり, 東北, 北 海道でも確認できる。 また, 東日本でピーク気温が 確認できない地域は標高の高い山間部と比較的よく 対応している. ピーク気温は北海道で $20^{\circ} \mathrm{C}$ 前後, 他 の地域では $24 \sim 28^{\circ} \mathrm{C}$ 程度である. 低緯度では高緯度 と比較してわずかにピーク気温が高い傾向が見られ るものの，気候区分間の特徵的な差は確認できない．

一方，冬季は一部を除きほとんどピークは見られ ない. ピークが存在する場合には, ピーク気温は夏 季とくらべて低く, 冬季だけで見ると, ピーク気温 は低緯度ほど高い傾向がある。

また。 ピーク気温が存在する地域の分布に, 気候 区分や地形との明確な対応は見られない.

\section{4. 考察}

日本域においては，冬季・夏季どちらについても 全体として極端な1時間降水強度と気温の間に正の 関係があり, 降水強度は気温と共に指数関数的に増 加することが確認された. ただし，この傾向は持続 的なものではなく, ある程度の気温に達すると降水 強度が減少に転じる傾向も確認された。

ピーク気温よりも低い気温における降水強度の変 化率は50パーセンタイルから99パーセンタイル降水 強度まで, 豪雨ほじその変化率が大きい傾向があり, ヨーロッパを対象とした例10),11) とよく一致する。こ の結果は稀な豪雨ほど気温変化の影響を受けやすい ことを示しており，水に関わる災害を考える上で重 要である.

今回解析した降水強度のうち最も稀な豪雨である 99パーセンタイル降水強度の変化率は, 領域7 (沖 縄周辺）, 領域6（九州・四国南部）を除き冬季は 飽和水蒸気量の変化率に近い $7 \%{ }^{\circ} \mathrm{C}^{-1}$ 付近に分布して いた。 今回の解析のみから気温と降水強度の直接の
因果関係を述べることはできないが，領域7（沖縄 周辺），領域6（九州・四国南部）を除く日本域に おける冬季の 1 時間降水量の極值は気温上昇に伴う 大気中が保持できる飽和水蒸気の量に大きく影響さ れている可能性がある。一方で冬季において領域7 （沖縄周辺），領域6（九州・四国南部）の降水強 度変化率が他の地域の変化率を大きく上回る傾向が あり, 気温増加に伴う降水強度の関係が $7 \%{ }^{\circ} \mathrm{C}^{-1}$ 前後 の值を示す傾向は, すべての地域について当てはま るものではないこともわかる. 特に領域7（沖縄周 辺）は日本においてもっとも低緯度に位置する点や 海に囲まれた地域である点において特徵的な地域で ある.今後はこうした点を考慮して今回確認された 地域間の傾向の差について更なる検討を行うことが 必要であろう。

また，夏季においては一様に $7 \%{ }^{\circ} \mathrm{C}^{-1}$ を回る変化 率であった。比較的高い気温において降水強度変化 率が $7 \%{ }^{\circ} \mathrm{C}-1$ を上回る傾向を示す点は, Lenderink and Meijgaard $^{10), 11)}$ らがヨーロッパについて解析した結果 と同様の傾向である。

高温ビンで降水強度が減少に転じる傾向が夏季に 顕著にみられた。降水強度の減少については, 本研 究とはタイムスケールの異なる24時間降水量に関し てではあるが, Berg et al. ${ }^{9}{ }^{9}$ が地域気候モデルの出力 した対流性降水に同様の傾向を見出している. Berg et al. ${ }^{9)}$ が解析を行った地域気候モデルの出力では, ヨーロッパにおいて対流性の降水の99パーセンタイ ル值がある気温以上で減少する傾向が冬季を除いて 見られており, 彼らはその原因を大気中の水蒸気量 の不足に求めた。本研究では 1 時間降水量の減少が 各季節の比較的高い気温で見られた. Berg et al. ${ }^{9)}$ と 同様に考えると，これは気温が高いほど大気が含み うる水蒸気の量が多くなる一方，水蒸気が飽和し凝 結するのに必要な水蒸気の量も多くなるため, ある 程度高温では降水に必要な水蒸気が十分に供給され ず降水強度が低下しているのではないかと考えられ る.

夏季にピーク気温が確認できない地域は標高の高 い山間部に比較的よく一致していた（図-5）。仮に ある季節におけるピーク気温が決まっていると考え ると, 標高の高い場所は標高の影響で気温が低く, 降水強度が減少に転じるピーク気温まで気温が上昇 しないためピーク気温が確認されないのではないか と推測できる. 実際, 図-3をみると夏季の領域2

(日本海沿岸）, 領域3 (太平洋沿岸) では $25^{\circ} \mathrm{C}$ 付

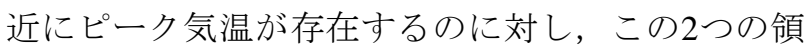
域に挟まれた山間部のみを抜き出した領域4（本州 内陸部）では, 気温が $25^{\circ} \mathrm{C}$ 程度まで上昇することが なく, ピーク気温は確認できない, なお, 降水強度 と地上気温の間に正の関係が見られるという傾向や, 降水強度の増加率については, 標高の影響を考慮す るためにいくつかの標高帯に分けて解析を行った場 合にも結果に大きな違いは見られなかった.

夏季の高温ビンにおける降水強度減少の原因とし 
ては，例えば夏季において日本が太平洋高気圧に覆 われているような場合が影響している可能性も考え られる.こうした状況では気温は高くなるものの, 日本における1時間降水量極值への寄与が大きいと 言われる前線の影響 $\left(\right.$ 木口・沖 ${ }^{12)}$ ) を受けにくい. こうした不一致が高い気温における降水強度の減少 となって現れている可能性もある。

\section{5. 結論}

本研究では, 降水強度が気温上昇と共に飽和水蒸 気量の変化率に近い割合で増加するとした Lenderink and Meijgaard ${ }^{10), 11}$ の結果を受けて, (a)そ もそもヨーロッパ以外でも極端な 1 時間降水強度と 地上気温の間に正の関係が見られるかどうか, (b) 正の関係が見られる場合, 降水強度の変化率は飽和 水蒸気量の変化率に近いものになるのか, (c) ヨー ロッパを対象にした解析が見ることのできなかった， より高い気温ではどのような傾向が見られるのか,

という疑問を背景として降水強度と地上気温の解析 を行った。 その結果, 日本域ではある程度の気温ま では極端な1時間降水強度と地上気温の関係は正の 関係を示すことがわかった．また冬季においては本 州〜北海道で気温上昇に伴う降水強度の増加率は飽 和水蒸気量の増加率に近い值を中心に分布していた. 一方, 特に沖縄周辺では飽和水蒸気量の変化率と比 較して大きな変化率になることが示され, 気温増加 に伴う降水強度の関係が $7 \%{ }^{\circ} \mathrm{C}^{-1}$ 前後の值を示す傾向 はすべての地域について当てはまるものではないこ ともわかった。 さらにパーセンタイルの取り方によ る降水強度増加率の違いを比較したところ, 50パー センタイルから99パーセンタイル降水強度まで, 豪 雨ほどその変化率が大きい傾向があった。

また, ある程度の気温以上で降水強度が減少に転 じる傾向があることも確認された。この傾向は夏季 に顕著であり, 降水強度が減少に転じる気温はおよ そ $25^{\circ} \mathrm{C}$ 前後であった. 冬季でも同様の傾向がわずか に見られたが，その気温は夏季よりも低かった。

本研究で確認された降水強度変化率の地域差や, 降水強度が減少に転じる気温の存在については, 海 岸からの距離や地形的な影響による水蒸気供給量の 多寡, 台風や前線による影響の受けや寸さなどが関 係している可能性がある. 今後こうした要因を考慮 することで, 今回確認されたような傾向の原因を探 ることができると考えられる.

GCMやRCM等の数值モデルが今回確認されたよ うな傾向を再現できているかどうかの確認も必要で ある. 再現できている場合, その点においては数值 モデルが現実をよく表現できていることになり，そ の信頼性を支持する一つの情報になる. また, 数值 モデルの出力の解析や追加的な実験を行うことで, 今回見られた傾向に対寸るより詳細な説明を与える ことができるだろう. 一方, 数値モデルによる再現 ができていない場合, 数值モデルによって得られる 極端な降水現象に関して, その結果をそのまま利用
することには慎重になる必要があるだろう.

謝辞 : 本研究は環境省環境研究総合推進費「温暖化 影響評価・適応政策に関寸る総合的研究」（課題番 号S-8）および文部科学省21世紀気候変動予測革新 プログラム「高解像度気候モデルによる近未来気候 変動予測に関する研究」の支援を受けて実施された。

\section{参考文献}

1)IPCC, 2007: Summary for Policymakers. In: Climate Change 2007: The Physical Science Basis. Contribution of Working Group I to the Fourth Assessment Report of the Intergovernmental Panel on Climate Change [Solomon, S., D. Qin, M. Manning, Z. Chen, M. Marquis, K.B. Averyt, M.Tignor and H.L. Miller (eds.)]. Cambridge University Press, Ca d mbridge, United Kingdom and New York, NY, USA.

2)Kanae, S., Oki, T., ,Kashida, A. Changes in hourly heavy precipitation at Tokyo from 1890 to 1999 . 気象集誌 82, 241- 247 (2004).

3)Fujibe, F., Yamazaki, N., Katsuyama, M. \& Kobayashi, K. The increasing trend of intense precipitation in Japan based on four-hourly data for a hundred years. SOLA 1, 41-44 (2005).

4)Trenberth, K.E., Dai, A., Rasmussen, R.M. \& Parsons, D.B. The changing character of precipitation. Bulletin of the American Meteorological Society 84, 1205-1217 (2003).

5)Emori, S. \& Brown, S.J. Dynamic and thermodynamic changes in mean and extreme precipitation under changed climate. Geophys. Res. Lett 32, L17706 (2005).

6)O'Gorman, P.A. \& Schneider, T. The physical basis for increases in precipitation extremes in simulations of 21stcentury climate change. Proceedings of the National Academy of Sciences 106, 14773-14777 (2009).

7)Sugiyama, M., Shiogama, H. \& Emori, S. Precipitation extreme changes exceeding moisture content increases in MIROC and IPCC climate models. Proceedings of the National Academy of Sciences 107, 571-575 (2010).

8)Allan, R.P. \& Soden, B.J. Atmospheric Warming and the Amplification of Precipitation Extremes. Science 321, 14811484 (2008).

9)Berg, P. et al. Seasonal characteristics of the relationship between daily precipitation intensity and surface temperature. Journal of Geophysical Research 114, D18102 (2009).

10)Lenderink, G. \& Van Meijgaard, E. Increase in hourly precipitation extremes beyond expectations from temperature changes. Nature Geoscience 1, 511-514 (2008).

11)Lenderink, G. \& Meijgaard, E. Linking increases in hourly precipitation extremes to atmospheric temperature and moisture changes. Environmental Research Letters 5, 025208 (2010).

12)木口 雅司, 沖 大幹: “世界 - 日本における雨量極值記 録”, 水文・水資源学会誌, Vol. 23, No. 3, pp.231-247, (2010).

(2010. 9. 30 受付) 